\title{
Peripheral Treatment with Enoxaparin, a Low Molecular Weight Heparin, Reduces Plaques and $\beta$-Amyloid Accumulation in a Mouse Model of Alzheimer's Disease
}

\author{
Luigi Bergamaschini, ${ }^{1 \star}$ Emanuela Rossi, ${ }^{1}$ Claudio Storini, ${ }^{2}$ Simone Pizzimenti, ${ }^{2}$ Maria Distaso,,${ }^{2}$ Carlo Perego, ${ }^{2}$ \\ Ada De Luigi, ${ }^{2}$ Carlo Vergani, ${ }^{1}$ and Maria Grazia De Simonii ${ }^{2 *}$ \\ ${ }^{1}$ Department of Internal Medicine, Ospedale Maggiore, Instituto di Ricovero e Cura a Carattere Scientifico, University of Milan, 20122 Milan, Italy, and \\ ${ }^{2}$ Department of Neuroscience, Mario Negri Institute for Pharmacological Research, Milan d015, Italy
}

\begin{abstract}
We investigated the effect of long-term, peripheral treatment with enoxaparin, a low molecular weight heparin, in transgenic mice overexpressing human amyloid precursor protein ${ }_{751}$. Enoxaparin (6 IU per mouse intraperitoneally, three times a week for 6 months) significantly lowered the number and the area occupied by cortical $\beta$-amyloid deposits and the total $\beta$-amyloid $(1-40)$ cortical concentration. Immunocytochemical analysis of glial fibrillary acid protein-positive cells showed that enoxaparin markedly reduced the number of activated astrocytes surrounding $\beta$-amyloid deposits. In vitro, the drug dose-dependently attenuated the toxic effect of $\beta$-amyloid on neuronal cells. Enoxaparin dose-dependently reduced the ability of $\beta$-amyloid to activate complement and contact systems, two powerful effectors of inflammatory response in AD brain. By reducing the $\beta$-amyloid load and cytotoxicity and proinflammatory activity, enoxaparin offers promise as a tool for slowing the progression of Alzheimer's disease.
\end{abstract}

Key words: Alzheimer; amyloid; A $\beta$; binding agent; low molecular weight heparin; APP23 mouse; inflammation; complement system; kinin system; heparin

\section{Introduction}

The etiology of Alzheimer's disease (AD) is still not known, but evidence is accumulating that an innate immune response from inside the $\mathrm{AD}$ brain is a secondary response to the early accumulation of $\beta$-amyloid $(\mathrm{A} \beta)$ antibody in the brain. This inflammatory event associated with amyloid plaques is thought to be a self-attack by the host on neurons, leading to exacerbation of the fundamental pathology through activation of microglia and astrocytes, increased expression of cytokines and acute phase reactants, and complement and contact-kinin system activation (Yasuhara et al., 1994; Bergamaschini et al., 2001a; McGeer and McGeer, 2001, 2002; van Beek et al., 2003).

Evidence that $\mathrm{A} \beta$ accumulation probably contributes to $\mathrm{AD}$ provides the rationale for a therapy based on altering brain $A \beta$ accumulation and reducing its cytotoxic and proinflammatory actions. Immunization with synthetic $\mathrm{A} \beta$ peptide (Schenk et al., 1999; Sigurdsson et al., 2001; Dodart et al., 2002) or administration of antibodies against $\mathrm{A} \beta$ (DeMattos et al., 2001; Chauhan and Siegel, 2002; Dodel et al., 2002; Mohajeri et al., 2002) reduces the pathology in an animal model of $\mathrm{AD}$ through a mechanism that might include crystallizable fragment of $\operatorname{Ig}(\mathrm{Fc})$ - and non- $\mathrm{Fc}$ -

Received Nov. 23, 2003; revised March 20, 2004; accepted March 21, 2004.

This work was supported by a grant from the Ministero della Sanità, Italy "Progetto Alzheimer 2000" and by Fondazione Monzino, Italy. We are indebted to Mirjana Carli and Claudia Balducci for skillful technical assistance.

*L.B. and M.G.D. contributed equally to this work.

Correspondence should be addressed to Dr. Luigi Bergamaschini, Department of Internal Medicine, 0spedale Maggiore, Instituto di Ricovero e Cura a Carattere Scientifico, Via Pace 9, 20122 Milano, Italy. E-mail: luigi.bergamaschini@unimi.it.

DOI:10.1523/JNEUROSCI.0550-04.2004

Copyright $\odot 2004$ Society for Neuroscience $\quad$ 0270-6474/04/244181-06\$15.00/0 mediated (Bard et al., 2000; Bacskai et al., 2002) clearance of $A \beta$ antibody complexes by activated microglia. Brain $A \beta$ levels may also be affected by the binding of $A \beta$ in blood, as suggested by the observation that immunological and non-immunological molecules with high $\mathrm{A} \beta$ binding affinity can reduce the formation of amyloid plaques by altering the brain-periphery dynamics (DeMattos et al., 2001; Dodart et al., 2002; Dodel et al., 2002; Matsuoka et al., 2003). In vitro, charged residues within the region $1-11$, and residues $13-16$, the H-H-Q-K domain, are critical for the proinflammatory activity of A $\beta$ (Velazquez et al., 1997; Webster et al., 1997a; Bergamaschini et al., 2001b) and microglia activation (Giulian et al., 1998), respectively. Thus, inhibition of these activities by pharmacological targeting of such regions might slow the neurodegeneration in $\mathrm{AD}$ brains. In this respect, heparins might be candidates for such therapy (Leveugle et al., 1994; Watson et al., 1997; Leveugle et al., 1998; Tyrrell et al., 1999; van Horssen et al., 2003). We have shown previously that native (unfractionated) heparin counteracts $A \beta$ neurotoxicity and its proinflammatory activity by attenuating its ability to activate the complement and contact systems in vitro (Bergamaschini et al., 2002). Because unfractionated heparin is not suitable for long-term therapy because of the difficulty in maintaining optimal therapeutic concentrations and the high risk of bleeding, we investigated the effect of the low molecular weight heparin (LMWH) enoxaparin (ENO) in BG,D2-Tg (Th1App)23/15dz/black mice (APP23) transgenic mice (Sturchler-Pierrat et al., 1997; Bayer et al., 2003). LMWHs, including ENO, are currently used in humans for anticoagulant therapy. Notably, they have been reported to reduce kidney amyloidosis in vivo (Kisilevsky et al., 1995; Zhu et al., 2001).

In addition to exploring its in vivo actions, we investigated 
whether ENO could attenuate the proinflammatory activity and cytotoxicity of $A \beta$ in vitro to gain an insight into its mechanism of action in APP23 mice.

\section{Materials and Methods}

Animals and ENO treatment. Six-month-old male APP23 mice (kindly provided by Dr. M. Staufenbiel, Novartis Pharma, Basel, Switzerland) (Sturchler-Pierrat et al., 1997; Bayer et al., 2003) were housed one mouse per cage in a controlled environment, with ad libitum access to food and water. Procedures involving animals and their care conformed to institutional guidelines that are in compliance with national (Decretolegge n.116, Gazzetta Ufficiale suppl. 40; February 18, 1992) and international laws and policies (EEC Council Directive 86/609, OJ L 358, 1; December 12, 1987; NIH Guide for the Care and Use of Laboratory Animals, United States National Research Council, 1996).

APP23 mice and their age-matched wild type (WT) mice were injected intraperitoneally with $6 \mathrm{IU}$ per mouse $(60 \mu \mathrm{g})$ of ENO (Aventis-Pharma, Milan, Italy) or saline, three times a week for 6 months. The dose of ENO corresponds to the clinically effective dose in humans $(250 \mathrm{IU} / \mathrm{kg})$. At the end of the treatment, mice were deeply anesthetized and transcardially perfused with $10 \mathrm{~mm}$ Tris buffer, $\mathrm{pH}$ 7.4, containing $10 \%$ sucrose, $1 \mathrm{~mm}$ EDTA, and 0.5 mm PMSF (all from Sigma Chemicals, St. Louis, MO). Brains were removed, and cortex and hippocampus were dissected from the right hemisphere and kept at $-80^{\circ} \mathrm{C}$ for biochemical and molecular assays. The other brain hemisphere was fixed in $4 \%$ paraformaldehyde, processed in $20-30 \%$ sucrose, frozen, and stored at $-80 \%$ for immunocytochemistry.

Sandwich ELISA for $A \beta(1-40)$. Total A $\beta$ (soluble and insoluble species) was obtained from the cortex of APP 23 and WT mice using a singlestep extraction with formic acid, adapting the method proposed by Lim et al. (2000). A mixture of protease inhibitors [1 mM 4-(2aminoethyl)benzenesulfonylfluoride, $\mathrm{HCl}, 0.8 \mu \mathrm{M}$ aprotinin, $50 \mu \mathrm{M}$ bestatin, $15 \mu \mathrm{M} \mathrm{E}-64,20 \mu \mathrm{M}$ leupeptin, $10 \mu \mathrm{M}$ pepstatin A; all from Calbiochem, La Jolla, CA and Novabiochem GmbH, San Diego, CA] was added to all solutions used for tissue extraction and ELISA measurements. Cortices were sonicated ( $10 \mathrm{~W}, 3 \times 10$ shots) in $3 \times$ wet weight $70 \%$ formic acid. Extracts were then neutralized with $2 \mathrm{~m}$ Tris, $\mathrm{pH} 8$, containing $30 \%$ acetonitrile and $2 \mathrm{M} \mathrm{NaOH}$ and centrifuged at 100,000 $\times$ $g$ for $1 \mathrm{hr}$ at $4^{\circ} \mathrm{C}$. The concentration of $\mathrm{A} \beta$ was measured by human $\beta$-amyloid (1-40) ELISA kit according to the manufacturer's instructions (Biosource International, Camarillo, CA). A standard A $\beta$ curve was plotted in neutralized formic acid and diluent buffer in the same ratio as for experimental samples.

Immunocytochemistry. Forty micrometer hemibrain cryostat coronal sections, prepared from perfused brains as described above, were used for assessment of $\mathrm{A} \beta$ deposits and astrocytic activation by glial fibrillary acidic protein (GFAP) immunostaining (De Simoni et al., 2000; Kalehua et al., 2000). For $A \beta$ immunostaining, sections were rinsed for $15 \mathrm{~min}$ in $3 \%$ fetal calf serum (FCS) (Hyclone Laboratories, Logan, UT) in $0.1 \mathrm{M}$ $\mathrm{PBS}$ and then incubated overnight with primary $\mathrm{A} \beta$ (mouse monoclonal human $A \beta$ protein, clone 4G8, 1:250; Signet Pathology System, Dedham, $\mathrm{MA})$. For GFAP immunostaining the sections were rinsed for $30 \mathrm{~min}$ in $0.4 \%$ Triton X-100 in PBS $0.1 \mathrm{~m}$ followed by $15 \mathrm{~min}$ in $0.1 \%$ Triton X-100 and $3 \%$ FCS in $0.1 \mathrm{~m}$ PBS. Sections were incubated overnight with GFAP (mouse monoclonal, 1:2500; Chemicon, Temecula, CA). For both stainings, sections were processed for conventional immunohistochemistry (De Simoni et al., 2000; Kalehua et al., 2000) the next day. We detected $A \beta$ deposits in GFAP-immunostained sections with alkaline Congo Red (Sigma). Sections were dehydrated through graded alcohols, fixed in xylene, coverslipped using DPX mountant (BDH Laboratory Supplies), and examined with bright-field and cross-polarized light photomicroscopy.

$A \beta$ deposits. After $A \beta$ immunostaining, six $20 \mu \mathrm{m}$ sections at $40 \mu \mathrm{m}$ intervals from one cerebral hemisphere were selected for $A \beta$ deposit count. The first section was at stereotaxic coordinates anteroposterior +3.20 from bregma. The number and total area $\left(\mu \mathrm{m}^{2}\right)$ of $A \beta$ immunopositive deposits in the cortex of each section were recorded and pooled for all six sections. Kontron Electronic KS300 Imaging System software interfaced with a Zeiss Axioskop microscope and a Grundig
Electronic video camera were used. The quantitative analysis was performed at $20 \times$ magnification by an investigator blinded to the treatment.

RNA isolation, cDNA synthesis, and real-time PCR. Total RNA was isolated from hippocampi according to the acid guanidium-phenolchloroform method, as described previously (De Simoni et al., 2000). cDNA was synthesized as follows: $1.5 \mu \mathrm{g}$ total RNA from each sample was reverse transcribed with random hexamer primers using Multi Scribe reverse transcriptase (TaqMan Reverse transcription reagents, Applied Biosystems, Foster City, CA). The following thermal cycling protocol for reverse transcription was used: $10 \mathrm{~min}$ at $25^{\circ} \mathrm{C}$ for incubation, $30 \mathrm{~min}$ at $48^{\circ} \mathrm{C}$ for reverse transcription, and then $5 \mathrm{~min}$ at $95^{\circ} \mathrm{C}$ for inactivation. Real-time PCR was performed using a GeneAmp 5700 Sequence detection System (Applied Biosystems). Fifty nanograms of cDNA and genespecific primers (200 nм final concentration) were added to Master Mix SYBR Green I Dye, TaqMan DNA polymerase, dNTPs with dUTP and optimal buffer components (Applied Biosystems) and subjected to PCR amplification in a total volume of $25 \mu$ l. The PCR protocol included one cycle at $50^{\circ} \mathrm{C}$ for $2 \mathrm{~min}$, one cycle at $95^{\circ} \mathrm{C}$ for $10 \mathrm{~min}$, and 40 cycles at $95^{\circ} \mathrm{C}$ for $15 \mathrm{sec}$ and $60^{\circ} \mathrm{C}$ for $1 \mathrm{~min}$. For each experimental group, six RNA samples were used. Real-time PCR was conducted in triplicate with each RNA sample. The amplified transcripts were quantified using the comparative cycle threshold method (Applied Biosystems users bulletin 2). Primer optimizing procedures and validation experiments (data not shown) were performed according to the manufacturer's instructions to show that efficiencies of target and reference were equal. Primers were designed using Primer Express software (Applied Biosystems) based on the following GenBank accession numbers (given in the parenthesis): IL-1 $\beta$ (NM008361), tumor necrosis factor- $\alpha$ ((NM013693), ICAM-1 (NM010493), and $\beta$-actin, the housekeeping gene (NM007393).

Preparation of $A \beta$ peptides. For all in vitro experiments, $A \beta$ peptides were prepared by dissolving lyophilized synthetic analog of $A \beta$ (1-40) and $A \beta$ (1-42) (both from Bachem, Bubendorf, Germany) in distilled $\mathrm{H}_{2} \mathrm{O}$ at a concentration of $50 \mu \mathrm{M}$ and immediately diluted to $25 \mu \mathrm{M}(100$ $\mu \mathrm{g} / \mathrm{ml}$ ) with PBS, pH 7.4, or PBS containing ENO (10, 50, and $100 \mu \mathrm{g} / \mathrm{ml}$ final concentrations). All $A \beta$ preparations were used within $30 \mathrm{~min}$ from dissolution; therefore solubilized $\mathrm{A} \beta$ peptides after storage at room temperature for $30 \mathrm{~min}$ were centrifuged $(10,000 \mathrm{rpm})$ for $10 \mathrm{~min}$ at room temperature, and the peptides, in supernatants and pellets, were morphologically characterized by light and electron microscopy. Congo Red staining was used for light microscopy examination of $A \beta$ preparations. Congo Red $(1 \mu \mathrm{l})$ was added to each sample $(20 \mu \mathrm{l})$ for $20 \mathrm{~min}$ at room temperature. Samples were applied on precoated glass slides and covered with cover glass, and slides were examined with a light microscope equipped with a polarizing filter. For negatively stained specimens, samples $(20 \mathrm{ml})$ were adsorbed to 200 mesh Formvar carbon-coated grids, air dried, and negatively stained with $2 \%$ uranyl acetate in water (w/v) for 2 min. The grids were examined and photographed in a Jeol JEM 1010 electron microscope operating at $80-100 \mathrm{kV}$.

Neuronal cell culture. Rat PC12 pheochromocytoma cells were maintained at $37^{\circ} \mathrm{C}$ with $5 \% \mathrm{CO}_{2}$ in gelatin-coated flasks with complete Roswell Park Memorial Institute (RPMI) 1640 medium (Seromed Biochrom, Berlin, Germany) containing complement-inactivated 10\% horse serum (Life Technologies, Paisley, UK) and 5\% fetal calf serum (Hyclone Laboratories). For neuronal differentiation, PC12 cells were removed from the flask with trypsin-EDTA $(0,25 \%$, Seromed Biochrom) and resuspended in the same medium at the density of $3 \times 10^{4} / \mathrm{ml}$. One hundred microliters of these cells were plated in collagen-coated wells $\left(3 \times 10^{3}\right.$ cells per well) and incubated at $37^{\circ} \mathrm{C}$ with $5 \% \mathrm{CO}_{2}$ for $24 \mathrm{hr}$. Medium was changed with complete RPMI 1640 supplemented with $1 \%$ horse serum and neuronal growth factor $(100 \mathrm{ng} / \mathrm{ml}$; Alomone Laboratories, Jerusalem, Israel) every $48 \mathrm{hr}$ for 10-14 d until complete differentiation. Differentiated PC12 cells are commonly considered a reliable model of neuronal cells.

Effect of ENO on $A \beta$ cytotoxicity. For $A \beta$ cytotoxicity, differentiated PC12 cells were incubated for $72 \mathrm{hr}$ in an equal volume of saline, ENO ( 1 , 5 , and $10 \mu \mathrm{M}), A \beta(1-40)$ or (1-42) (both $25 \mu \mathrm{M}$ ), or a mixture of $A \beta$ $(1-40)$ or $(1-42)$ and ENO at the three doses. At the end of incubation, cell viability was evaluated by measuring the conversion of tetrazolium bromide (MTT) (Sigma) to insoluble purple formazan. The reaction 
A

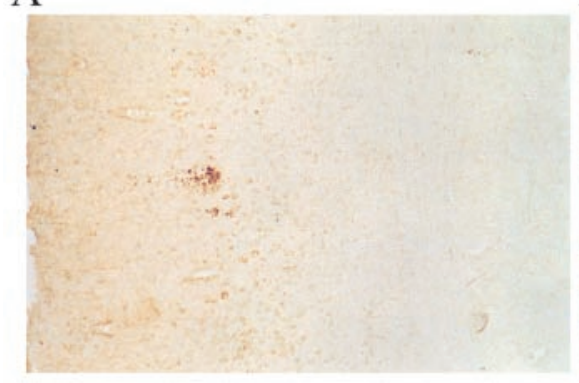

C

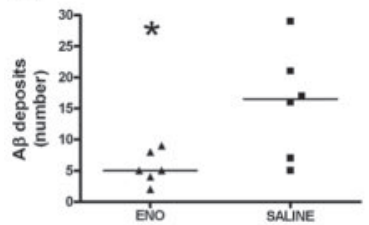

D

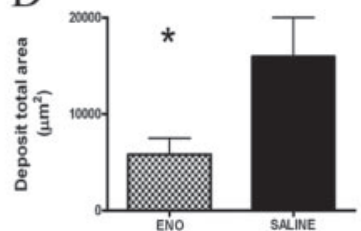

B

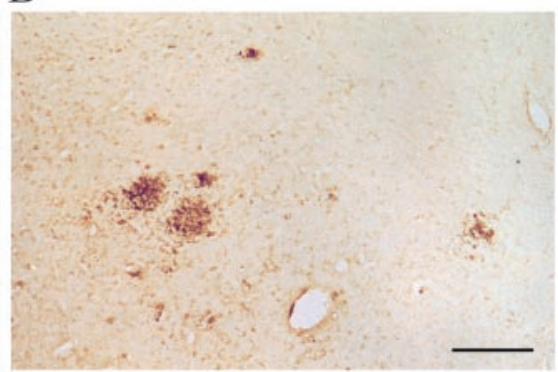

$\mathrm{E}$

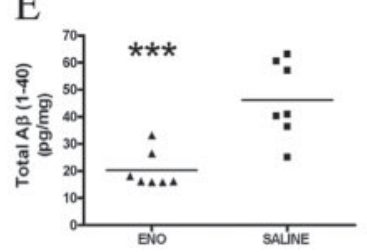

Figure 1. ENO reduces the antibody load in APP23 mice. Representative photomicrographs of $40 \mu \mathrm{m}$ prefrontal cortex slices prepared from APP23 transgenic mice are shown. Immunostaining for A $\beta$ revealed few small amyloid deposits in mice treated with ENO $(A)$ but several deposits in mice given saline $(B)$. Scale bar, $200 \mu \mathrm{m}$. $C-E$, In cortex slices of APP 23 mice treated with EN 0 or saline, the $A \beta$ load was quantified by evaluating the number of $A \beta$ deposits (horizontal bar indicates the median; ${ }^{*} p<0.02$ vs saline; Student's $t$ test) $(C)$, the total area occupied by deposits (mean $\pm \mathrm{SE} ;{ }^{*} p<0.03$ vs saline; Student's $t$ test) $(D)$, and the total, soluble plus insoluble, $A \beta$ $(1-40)$ concentration (horizontal bar indicates the mean; ${ }^{* * *} p<0.001$ vs saline; Student's $t$ test) $(E)$

and contact system factors, and HAG and kaolin were used as positive controls to activate the complement and contact systems, respectively, in vitro. HAG was prepared by incubating human $\mathrm{IgG}_{1}$ myeloma protein $(20 \mathrm{mg} / \mathrm{ml})$ at $56^{\circ} \mathrm{C}$ for $30 \mathrm{~min}$. The effect of heparin sulfate (HS) (Sigma) and dermatan sulfate (DS) (Sigma), other members of the glycosaminoglycan family, was also tested.

\section{Results}

Effect of peripheral ENO treatment in APP23 transgenic mice

To explore the effects of ENO in vivo, we chronically treated 6-month-old APP23 transgenic mice (overexpressing human $\left.\mathrm{APP}_{751}\right)$. These mice develop $\mathrm{A} \beta$ deposits, a hallmark of $\mathrm{AD}$ neuropathology, in the cortex and hippocampus starting from 5 months of age. Most of the deposits are compact at their first appearance (SturchlerPierrat et al., 1997; Bornemann and Staufenbiel, 2000).

APP23 mice and their age-matched WT mice were injected with 6 IU of ENO (60 $\mu$ g, i.p.) or saline per mouse three times a week for 6 months. At the end of the treatment, quantitative imaging analy-

product was analyzed spectrophotometrically at $540 \mathrm{~nm}$ with an automated microplate reader. MTT is a water-soluble tetrazolium salt that is converted to insoluble purple formazan by dehydrogenase enzymes. Because active mitochondrial dehydrogenases of living cells, but not of dead cells, will cause MTT conversion, this method is used as a measurement of cell viability (Martel et al., 1997).

Contact system activation. Contact system activation was assessed by measuring the degree of cleavage of high molecular weight kininogen (HK), a suitable marker of contact system activation (Berrettini et al., 1986), using densitometric analysis of immunostained blotting membranes after SDS-PAGE. This method simultaneously evaluates the native protein and its activation fragment. Plasma samples were loaded on $8 \%$ acrylamide gel and separated by SDS under nonreducing conditions. Proteins were transferred to polyvinylidene-difluoride membranes (Immobilon, Millipore, Bedford, MA) by electroblotting, and HK bands were visualized with polyclonal goat anti-light chain HK (Nordic, Thilburg, The Netherlands) and biotin-conjugated rabbit anti-goat IgG (Sigma) and an avidin-alkaline phosphatase substrate (Sigma). The blotting membranes were analyzed with a high-performance scanner and Image Master software (Amersham Biosciences, Uppsala, Sweden). The level of HK activation was expressed as the percentage of total protein (band II plus III versus bands I plus II and III). The apparent masses of native $\mathrm{HK}$ and its activation fragments were molecular weights 130,000 (band I), 107,000 (band II), and 98,000 (band III).

Complement activation. Complement activation was assessed by measuring the degree of $\mathrm{C} 4$ cleavage essentially as described for the contact system. The $\mathrm{C} 4$ bands were visualized with rabbit polyclonal anti-C4/C4c (Dako, Glostrup, Denmark) and biotin-conjugated goat anti-rabbit IgG (Sigma) and an avidin-alkaline phosphatase substrate (Sigma). C4 activation was expressed as the percentage of total protein (band II versus bands I plus II).

Effect of ENO on the A $\beta$-dependent activation of complement and contact systems. Freshly solubilized $A \beta(1-40)$ or $(1-42)(100 \mu \mathrm{g} / \mathrm{ml}, 100$ $\mu \mathrm{l})$, heat-aggregated human IgG (HAG) $(20 \mathrm{mg} / \mathrm{ml} 10 \mu \mathrm{l})$, or $1 \%$ kaolin $(10 \mu \mathrm{l})$ (Sigma) was incubated for $30 \mathrm{~min}$ at $37^{\circ} \mathrm{C}$ with normal Nacitrated plasma containing different amounts of ENO $(0,10,50$, and 100 $\mu \mathrm{g} / \mathrm{ml}$, corresponding to $0,0.5,1$, and $2 \mathrm{~mm}$ respectively). The reaction was quenched by adding $200 \mu \mathrm{l}$ of PBS containing soybean trypsin inhibitor $(100 \mu \mathrm{g} / \mathrm{ml})$, EDTA (10 mM), and Polybrene (0.05\% v/w) (all from Sigma). Normal Na-citrated plasma was the source of complement sis of $\mathrm{A} \beta$ deposits showed a significant reduction in number and area occupied by amyloid deposits in the neocortex, compared with saline-treated APP23 mice (Fig. $1 A-D$ ). Quantification of the formic acid-extracted (i.e., total: soluble plus insoluble) $\mathrm{A} \beta$ (1-40) content in the cortex of these mice showed that the $\mathrm{A} \beta$ concentration was significantly lower in mice receiving ENO (Fig. $1 E$ ). In WT mice, $\mathrm{A} \beta$ was undetectable. Because activated glial cells are present around $A \beta$ plaques as a result of the local inflammatory state elicited by $A \beta$, we checked for the presence of GFAP-immunopositive astrocytes in mice receiving ENO or saline (Fig. 2). Astrocytes showing an activated phenotype with enlarged cell bodies and long thick processes were found selectively around $\mathrm{A} \beta$ deposits in APP23 mice treated with saline. Only few, faintly stained, thin astrocytes were observed in the cortical tissue of ENO-treated mice, indicating a marked reduction in the astrocytic response.

The chronic treatment with ENO was well tolerated and did not elicit appreciable side effects as indicated by absence of hemorrhage in the brain and by the lack of significant differences in hippocampal mRNA expression of the inflammatory genes tested (IL-1 $\beta: F=3.46, p=0.87$; TNF- $\alpha: F=3.26, p=0.932$; ICAM-1: $F=3.98, p=0.743$; two-way ANOVA) (supplemental Table 1, available at www.jneurosci.org).

\section{Effect of ENO on $A \beta$ aggregation state in vitro}

Because $A \beta$ toxicity in vitro might be related to its aggregation state, we checked whether ENO affected it under our experimental conditions, i.e., 30 min of incubation with $\mathrm{A} \beta$ at room temperature. Under light microscopy, $\mathrm{A} \beta$ and $\mathrm{A} \beta$ plus ENO (0.5-2 $\mathrm{mm}$ ) preparations lacked any visible indications of precipitated aggregates, in both supernatants and pellets. Electron microscopy evaluation revealed that fibrils were poorly present in all preparations and that there was some increase in fibrillation at the highest concentration of ENO. Fibril morphology was similar in all $\mathrm{A} \beta$ and $\mathrm{A} \beta$ plus ENO preparations; the diameter of fibrils ranged between 40 and $52 \AA$ (data not shown). 
A

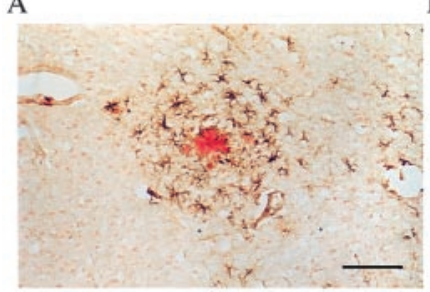

$\mathrm{C}$

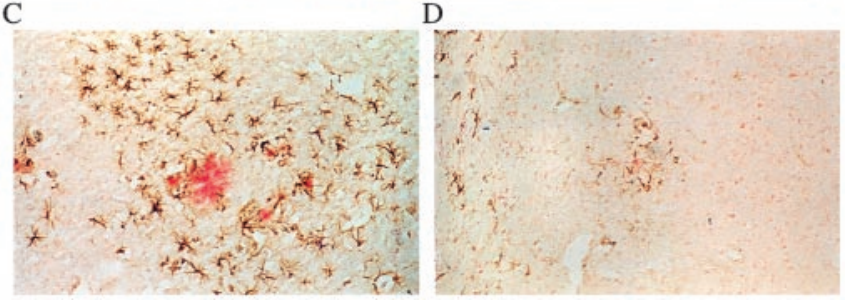

Figure 2. EN0 reduces astrocyte activation in APP23 mice. Shown are representative photomicrographs of $40 \mu \mathrm{m}$ prefrontal cortex slices prepared from APP23 transgenic mice, showing GFAP-immunopositive astrocytes. Activated astrocytes with enlarged cell bodies and highly ramified, thick processes surround fibrillar amyloid deposits (stained with Congo Red) in APP23 mice treated with saline $(A, C$. Only a few, scattered GFAP-positive cells can be observed in APP23 mice treated with ENO $(B, D)$, indicating that the treatment markedly reduced astrocyte activation. Scale bar, $100 \mu \mathrm{m}$.

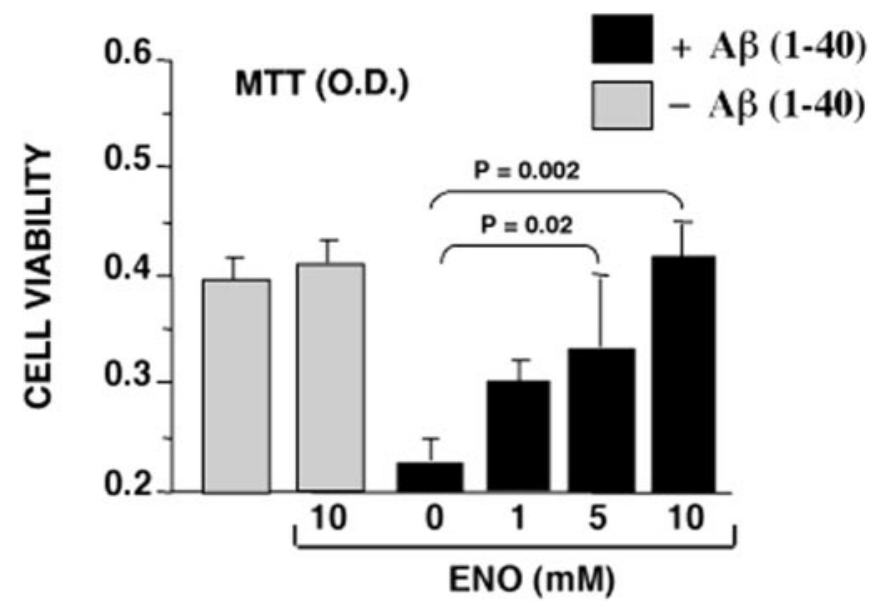

Figure 3. ENO dose-dependently attenuates $A \beta(1-40)$ cytotoxicity. The viability of differentiated PC12 cells was measured by densitometric analysis of surviving cells stained with MTT. Cells $\left(15 \times 10^{3} / \mathrm{cm}^{2}\right)$ were exposed to $\mathrm{A} \beta(1-40)(25 \mu \mathrm{M})$ or $\mathrm{A} \beta$ plus ENO at different concentrations $(1,5$, and $10 \mathrm{~mm})$ for $72 \mathrm{hr}$. Data are the mean \pm SE optical density (0.D.). ${ }^{* *} p<$ $0.01 ;{ }^{* * *} p<0.001$ vs $A \beta$ alone; ANOVA followed by Tukey's test).

\section{ENO attenuates $A \beta(1-40)$ and (1-42) cytotoxicity in vitro}

We assessed whether ENO attenuated $\mathrm{A} \beta$ cytotoxicity using rat adrenal pheochromocytoma PC12 cells grown in the presence of neuronal growth factor to obtain complete differentiation into neuronal cells. ENO per se (up to $25 \mu \mathrm{M}$; data not shown) had no effect on differentiated PC12 cell viability, but it reduced the cytotoxic effect of $A \beta$ (1-40) in a dose-dependent manner (Fig. 3). Similar results were obtained using $\mathrm{A} \beta$ (1-42) (data not shown).

\section{ENO attenuates $A \beta(1-40)$ and (1-42) proinflammatory activities in vitro}

We investigated whether ENO, like unfractionated heparin (Bergamaschini et al., 2002), attenuated $\mathrm{A} \beta$ toxicity by measuring the $A \beta$-driven activation of the complement and contact-kinin systems in vitro. These systems are powerful effectors of inflamma- tory reactions and are thought to be involved in progressive AD neurodegeneration.

Enoxaparin dose-dependently reduced the ability of $A \beta$ (1$40)$ to activate the complement and contact systems, as shown by the decrease in the activation bands of complement classical pathway (C4c) and of the contact system (HK bands II and III) (Fig. 4). Identical results were obtained using $A \beta$ (1-42). The ability to prevent activation of these systems seems to be a characteristic of enoxaparin, because HS and DS, other members of the glycosaminoglycan family, have no such effect. Moreover, HS and DS, even at the lowest concentration used in our experiments $(10 \mu \mathrm{M})$, activated the complement and contact systems directly.

\section{Discussion}

This study found that prophylactic treatment with a clinically relevant dose of ENO, which has anti-inflammatory and cytoprotective effects in vitro, reduced reactive astrocytosis, the deposition of $\mathrm{A} \beta$, and its total brain concentration in an animal model of $\mathrm{AD}$. We did not address the effect of prophylactic treatment with ENO on APP23 behavioral changes because these mice (male, 12 months old) do not manifest significant cognitive impairment (Kelly et al., 2003). The absence of an inflammatory reaction (supplemental Table 1) and brain hemorrhages suggests that long-term treatment with ENO was well tolerated.

Whether the protective effect of ENO is caused by a decrease in amyloidogenesis (Zhu et al., 2001) or the prevention of $A \beta$ brain deposition, or both, is not yet clear. There are at least two possible sites of action of ENO in vivo. First, ENO may act in the CNS, although it is still not understood whether LMWHs, including ENO, can cross the blood-brain barrier (BBB) (Dudas et al., 2002; Ma et al., 2002; Walzer et al., 2002). The BBB has never been clearly seen to be damaged in $\mathrm{AD}$, but there is evidence that the pathological elevation of soluble $A \beta$ in plasma may alter the permeability of brain capillaries (Zlokovic et al., 1993; Mackic et al., 1998; Strazielle et al., 2000; Ma et al., 2002), facilitating the passage of small molecules such as ENO. In the CNS, small amounts of the drug, which may affect the interactions between heparin sulfate and amyloid protein, might prevent $\mathrm{A} \beta$ deposition by impeding the structural changes necessary for fibril formation (Kisilevsky, 1997; Shuvaev and Siest, 2000; Zhu et al., 2001; Bazin et al., 2002). In addition, ENO may also protect neurons from the toxicity of soluble $\mathrm{A} \beta$, as suggested by our data on cultured neuronal cells. In vitro, in our experimental conditions, ENO had no effect on $\mathrm{A} \beta$ fibrillarity, indicating that the neuroprotective effect of ENO was not caused by a change in $\mathrm{A} \beta$ conformation or aggregation state. Because heparin binds to the 13-16 residues of $\mathrm{A} \beta$ (HHQK domain), it is possible that ENO may have coated $\mathrm{A} \beta$ fibrils in such a way that they cannot interact efficiently with the neuronal or PC12 cell membrane. Alternatively, although the two mechanisms are not mutually exclusive, ENO could have eluted cell-bound A $\beta$ (Mackic et al., 1998), preventing its toxic effects. Notably, targeting of interactions of the HHQK domain within $A \beta$ with microglia attenuated the neurotoxic effects of microglia in vitro and reduced inflammation in vivo (Giulian et al., 1998). Although we could not evaluate possible ENO-mediated neuroprotective effect in vivo because APP23 mice do not develop noticeable cortical neurodegeneration (Calhoun et al., 1998), astrocyte activation was markedly reduced in ENO-treated mice.

A second possible site of action of ENO in vivo is blood. Apart from its pharmacological actions in the brain, ENO may also interact with circulating $\mathrm{A} \beta$, thereby altering its brain-plasma 
A
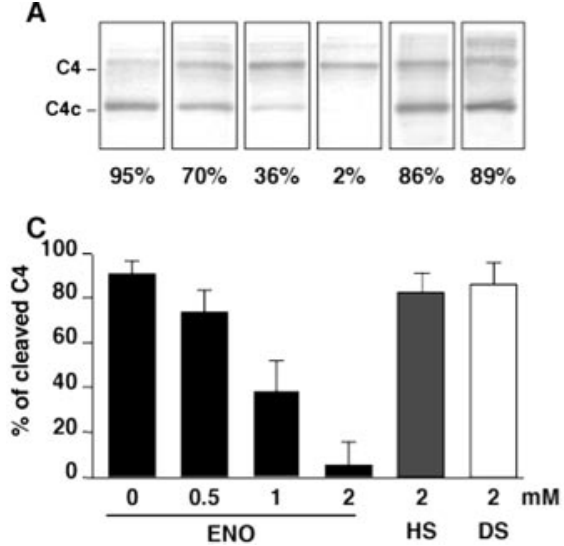

B

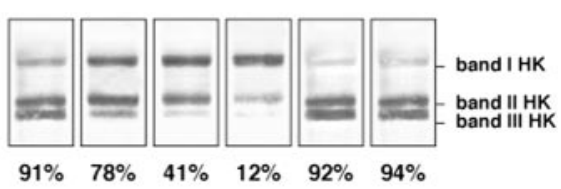

D

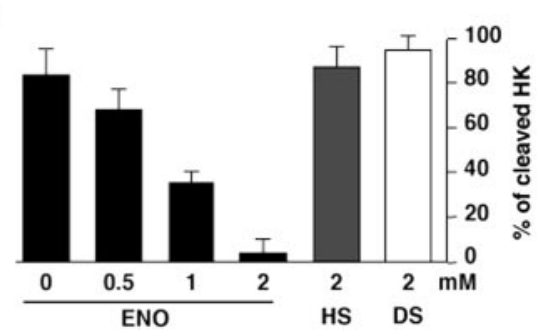

Figure 4. ENO inhibits $A \beta(1-40)$-dependent activation of the complement and contact systems. Shown is representative SDS-PAGE and Western blotting analysis of the cleavage of $C 4(A)$ and $H K(B)$ as indicators of complement and contact system activation, respectively. At the bottom of each lane, the percentages of cleaved C4 (C4 v vs C4 plus C4c) and HK (bands II and III vs I plus II and III) were determined by densitometric analysis of the immunostained membrane. ENO but not DS or HS caused dose-dependent inhibition of the cleavage of $(4$ and HK induced by $A \beta(25 \mu \mathrm{M})$. Columns show the mean $\pm \mathrm{SE}(\%)$ of $\mathrm{C} 4(\mathrm{C})$ and HK (D) cleavage in three separate experiments run in triplicate ${ }^{* *} p>0.01 ;{ }^{* * *} p>0.001$ vs $A \beta$ alone; Kruskal-Wallis followed by Dunn's test).

dynamics (Bard et al., 2000; Dodart et al., 2002; Dodel et al., 2002; Matsuoka et al., 2003).

Our in vitro findings that ENO reduces the ability of soluble $A \beta$ to activate the complement and contact systems in human plasma indicate that even in the presence of its physiologic ligands, specifically anti-thrombin III, ENO can attenuate $\mathrm{A} \beta$ biological activity. The inhibitory mechanism of ENO probably involves an interaction with $\mathrm{A} \beta$ and not with the plasma factors of those systems, because ENO, like natural heparin (Bergamaschini et al., 2002), has no effect on the activating ability of HAG and kaolin, activators of the complement classical pathway and contact system, respectively (data not shown).

The complement and contact systems, which are believed to be involved in $\mathrm{AD}$ pathology, are powerful effector mechanisms of the immune system. Although their activation contributes to the development of an inflammatory reaction to protect the host, chronic or unregulated activation of these systems can result in destructive inflammatory events and tissue damage. In AD brains, complement activation products may enhance the inflammatory response by synergizing with $\mathrm{A} \beta$ to induce the production of proinflammatory cytokines and could participate in $A \beta$ neurotoxicity through the generation of anaphylatoxins (C3a, C5a) and of the cytolytic complex C5b-9 (Webster et al., 1997b; Terryberry et al., 1998; O'Barr and Cooper, 2000; McGeer and McGeer, 2002; Farkas et al., 2003; van Beek et al., 2003; Veerhuis et al., 2003). There is also evidence of a protective role for complement in $\mathrm{AD}$ pathology, because overexpression of the natural inhibitor C3 in APP transgenic mice results in an increase of $\mathrm{A} \beta$ deposition and neuronal loss (Wyss-Coray et al., 2002). The situation in the brain compartment where $\mathrm{A} \beta$ peptides accumulate is likely to be very complex, and it is possible that complement protective or toxic effects are threshold phenomena, so that above a given level of complement activation, cells, including neurons, are injured. The beneficial effects observed in our transgenic mice might also be achieved through a dampening of the local glial reactions, as indicated by the reduction of astrocyte activation around $A \beta$ deposits.

In conclusion, it would appear that a dose of ENO similar to the clinically effective dose in humans, administered in the early phase of the disease, attenuates brain $A \beta$ accumulation and deposition. $\mathrm{Al}-$ though $A \beta$ deposition is probably only one of the pathogenetic fac-

tors, our findings further support the hypothesis that LMWH might be beneficial against the progression of $\mathrm{AD}$ (Walzer et al., 2002). LMWHs, including ENO, are used extensively for anticoagulation, but anticoagulant therapy is usually too short to allow a retrospective study. The fact that the animal models available at present do not reproduce all the characteristics of $\mathrm{AD}$, and that $\mathrm{LM}$ WHs, including ENO are easy to use, have few and well known side effects, and are suitable for long-term therapy (Lee et al., 2003), argues in favor of a clinical trial to check the beneficial effects of this drug in a therapeutic setting.

\section{References}

Bacskai BJ, Kajdasz ST, McLellan ME, Games D, Seubert P, Schenk D, Hyman BT (2002) Non-Fc-mediated mechanisms are involved in clearance of amyloid- $\beta$ in vivo by immunotherapy. J Neurosci 22:7873-7878.

Bard F, Cannon C, Barbour R, Burke RL, Games D, Grajeda H, Guido T, Hu K, Huang J, JohnsonWood K, Khan K, Kholodenko D, Lee M, Lieberburg I, Motter R, Nguyen M, Soriano F, Vasquez N, Weiss K, Welch B, et al. (2000) Peripherally administered antibodies against amyloid beta-peptide enter the central nervous system and reduce pathology in a mouse model of Alzheimer disease. Nat Med 6:916-919.

Bayer TA, Schafer S, Simons A, Kemmling A, Kamer T, Tepests R, Eckert A, Schussel K, Eikenberg O, Sturchler-Pierrat C, Abramowski D, Staufenbiel M, Multhaup G (2003) Dietary Cu stabilizes brain superoxide dismutase 1 activity and reduces amyloid Abeta production in APP23 transgenic mice. Proc Natl Acad Sci USA 100:14187-14192.

Bazin HG, Marques MA, Owens III AP, Linhardt RJ, Crutcher KA (2002) Inhibition of apolipoprotein E-related neurotoxicity by glycosaminoglycans and their oligosaccharides. Biochemistry 41:8203-8211.

Bergamaschini L, Donarini C, Gobbo G, Parnetti L, Gallai V (2001a) Activation of complement and contact system in Alzheimer's disease. Mech Ageing Dev 122:1971-1983.

Bergamaschini L, Donarini C, Foddi C, Gobbo G, Parnetti L, Agostoni A (2001b) The region 1-11 of Alzheimer amyloid-beta is critical for activation of contact-kinin system. Neurobiol Aging 22:63-69.

Bergamaschini L, Donarini C, Rossi E, De Luigi A, Vergani C, De Simoni MG (2002) Heparin attenuates cytotoxic and inflammatory activity of Alzheimer amyloid-beta in vitro. Neurobiol Aging 23:531-536.

Berrettini M, Lammle B, White T, Heeb MJ, Schwarz HP, Zuraw B, Curd J, Griffin JH (1986) Detection of in vitro and in vivo cleavage of high molecular weight kininogen in human plasma by immunoblotting with monoclonal antibodies. Blood 68:455-462.

Bornemann KD, Staufenbiel M (2000) Transgenic mouse models of Alzheimer's disease. Ann NY Acad Sci 908:260-266.

Calhoun ME, Wiederhold KH, Abramowski D, Phinney AL, Probst A, Sturchler-Pierrat C, Staufenbiel M, Sommer B, Jucker M (1998) Neuron loss in APP transgenic mice. Nature 395:755-756.

Chauhan NB, Siegel GJ (2002) Reversal of amyloid beta toxicity in Alzheimer's disease model $\mathrm{Tg} 2576$ by intraventricular anti-amyloid beta antibody. J Neurosci Res 69:10-23.

DeMattos RB, Bales KR, Cummins DJ, Dodart JC, Paul SM, Holtzman DM (2001) Peripheral anti-A beta antibody alters CNS and plasma A beta clearance and decreases brain A beta burden in a mouse model of Alzheimer's disease. Proc Natl Acad Sci USA 98:8850-8855.

De Simoni MG, Perego C, Ravizza T, Moneta D, Conti M, Marchesi F, De Luigi A, Garattini S, Vezzani A (2000) Inflammatory cytokines and related genes are induced in the rat hippocampus by limbic status epilepticus. Eur J Neurosci 12:2623-2633.

Dodart JC, Bales KR, Gannon KS, Greene SJ, DeMattos RB, Mathis C, DeLong CA, Wu S, Wu X, Holtzman DM, Paul SM (2002) Immunization reverses memory deficits without reducing brain Abeta burden in Alzheimer's disease model. Nat Neurosci 5:452-457. 
Dodel R, Hampel H, Depboylu C, Lin S, Gao F, Schock S, Jackel S, Wei X, Buerger K, Hoft C, Hemmer B, Moller HJ, Farlow M, Oertel WH, Sommer N, Du Y (2002) Human antibodies against amyloid beta peptide: a potential treatment for Alzheimer's disease. Ann Neurol 52:253-256.

Dudas B, Cornelli U, Lee JM, Hejna MJ, Walzer M, Lorens SA, Mervis RF, Fareed J, Hanin I (2002) Oral and subcutaneous administration of the glycosaminoglycan C3 attenuates Abeta(25-35)-induced abnormal tau protein immunoreactivity in rat brain. Neurobiol Aging 23:97-104.

Farkas I, Takahashi M, Fukuda A, Yamamoto N, Akatsu H, Baranyi L, Tateyama H, Yamamoto T, Okada N, Okada H (2003) Complement $\mathrm{C} 5 \mathrm{a}$ receptor-mediated signaling may be involved in neurodegeneration in Alzheimer's disease. J Immunol 170:5764-5771.

Giulian D, Haverkamp LJ, Yu J, Karshin W, Tom D, Li J, Kazanskaia A, Kirkpatrick J, Roher AE (1998) The HHQK domain of beta-amyloid provides a structural basis for the immunopathology of Alzheimer's disease. J Biol Chem 273:29719-29726.

Kalehua AN, Taub DD, Baskar PV, Hengemihle J, Munoz J, Trambadia M, Speer DL, De Simoni MG, Ingram DK (2000) Aged mice exhibit greater mortality concomitant to increased brain and plasma TNF-alpha levels following intracerebroventricular injection of lipopolysaccharide. Gerontology 46:115-128.

Kelly PH, Bondolfi L, Hunziker D, Schlecht HP, Carver K, Maguire E, Abramowski D, Wiederhold KH, Sturchler-Pierrat C, Jucker M, Bergmann R, Staufenbiel M, Sommer B (2003) Progressive age-related impairment of cognitive behavior in APP23 transgenic mice. Neurobiol Aging 24:365-378.

Kisilevsky R (1997) Can deposition of amyloid be prevented in Alzheimer's disease? Ann NY Acad Sci 826:117-127.

Kisilevsky R, Lemieux LJ, Fraser PE, Kong X, Hultin PG, Szarek WA (1995) Arresting amyloidosis in vivo using small-molecule anionic sulphonates or sulphates: implications for Alzheimer's disease. Nat Med 1:143-148.

Lee AY, Levine MN, Baker RI, Bowden C, Kakkar AK, Prins M, Rickles FR, Julian JA, Haley S, Kovacs MJ, Gent M (2003) Low-molecular-weight heparin versus a coumarin for the prevention of recurrent venous thromboembolism in patients with cancer. N Engl J Med 349:146-153.

Leveugle B, Scanameo A, Ding W, Fillit H (1994) Binding of heparin sulfate glycosaminoglycan to beta-amyloid peptide: inhibition by potentially therapeutic polysulfated compounds. NeuroReport 5:1389-1392.

Leveugle B, Ding W, Laurence F, Dehouck MP, Scanameo A, Cecchelli R, Fillit H (1998) Heparin oligosaccharides that pass the blood-brain barrier inhibit beta-amyloid precursor protein secretion and heparin binding to beta-amyloid peptide. J Neurochem 70:736-744.

Lim GP, Yang F, Chu T, Chen P, Beech W, Teter B, Tran T, Ubeda O, Ashe KH, Frautschy SA, Cole GM (2000) Ibuprofen suppresses plaque pathology and inflammation in a mouse model for Alzheimer's disease. J Neurosci 20:5709-5714.

Ma Q, Dudas B, Hejna M, Cornelli U, Lee JM, Lorens S, Mervis R, Hanin I, Fareed J (2002) The blood-brain barrier accessibility of a heparinderived oligosaccharides C3. Thromb Res 105:447-453.

Mackic JB, Stins M, McComb JG, Calero M, Ghiso J, Kim KS, Yan SD, Stern D, Schmidt AM, Frangione B, Zlokovic BV (1998) Human blood-brain barrier receptors for Alzheimer's amyloid-beta 1-40. Asymmetrical binding, endocytosis, and transcytosis at the apical side of brain microvascular endothelial cell monolayer. J Clin Invest 102:734-743.

Martel CL, Mackic JB, Matsubara E, Governale S, Miguel C, Miao W, McComb JG, Frangione B, Ghiso J, Zlokovic BV (1997) Isoform-specific effects of apolipoproteins E2, E3, and E4 on cerebral capillary sequestration and blood-brain barrier transport of circulating Alzheimer's amyloid beta. J Neurochem 69:1995-2004.

Matsuoka Y, Saito M, LaFrancois J, Gaynor K, Olm V, Wang L, Casey E, Lu Y, Shiratori C, Lemere C, Duff K (2003) Novel therapeutic approach for the treatment of Alzheimer's disease by peripheral administration of agents with an affinity to $\beta$-amyloid. J Neurosci 23:29-33.

McGeer PL, McGeer EG (2001) Inflammation, autotoxicity and Alzheimer disease. Neurobiol Aging 22:799-809.

McGeer PL, McGeer EG (2002) The possible role of complement activation in Alzheimer disease. Trends Mol Med 8:519-523.

Mohajeri MH, Saini K, Schultz JG, Wollmer MA, Hock C, Nitsch RM (2002) Passive immunization against beta-amyloid peptide protects central nervous system (CNS) neurons from increased vulnerability associated with an Alzheimer's disease-causing mutation. J Biol Chem 277:33012-33017.
O'Barr S, Cooper NR (2000) The C5a complement activation peptide increases IL-1beta and IL-6 release from amyloid-beta primed human monocytes: implications for Alzheimer's disease. J Neuroimmunol 109:87-94.

Schenk D, Barbour R, Dunn W, Gordon G, Grajeda H, Guido T, Hu K, Huang J, Johnson-Wood K, Khan K, Kholodenko D, Lee M, Liao Z, Lieberburg I, Motter R, Mutter L, Soriano F, Shopp G, Vasquez N, Vandevert C, et al. (1999) Immunization with amyloid-beta attenuates Alzheimer-diseaselike pathology in the PDAPP mouse. Nature 400:173-177.

Shuvaev VV, Siest G (2000) Heparin specifically inhibits binding of apolipoprotein E to amyloid beta-peptide. Neurosci Lett 280:131-134.

Sigurdsson EM, Scholtzova H, Mehta PD, Frangione B, Wisniewski T (2001) Immunization with a nontoxic/nonfibrillar amyloid-beta homologous peptide reduces Alzheimer's disease-associated pathology in transgenic mice. Am J Pathol 159:439-447.

Strazielle N, Ghersi-Egea JF, Ghiso J, Dehouck MP, Frangione B, Patlak C, Fenstermacher J, Gorevic P (2000) In vitro evidence that beta-amyloid peptide 1-40 diffuses across the blood-brain barrier and affects its permeability. J Neuropathol Exp Neurol 59:29-38.

Sturchler-Pierrat C, Abramowski D, Duke M, Wiederhold KH, Mistl C, Rothacher S, Ledermann B, Burki K, Frey P, Paganetti PA, Waridel C, Calhoun ME, Jucker M, Probst A, Staufenbiel M, Sommer B (1997) Two amyloid precursor protein transgenic mouse models with Alzheimer disease-like pathology. Proc Natl Acad Sci USA 94:13287-13292.

Terryberry JW, Thor G, Peter JB (1998) Autoantibodies in neurodegenerative diseases: antigen-specific frequencies and intrathecal analysis. Neurobiol Aging 19:205-216.

Tyrrell DJ, Horne AP, Holme KR, Preuss JM, Page CP (1999) Heparin in inflammation: potential therapeutic applications beyond anticoagulation. Adv Pharmacol 46:151-208.

van Beek J, Elward K, Gasque P (2003) Activation of complement in the central nervous system: roles in neurodegeneration and neuroprotection. Ann NY Acad Sci 992:56-71.

van Horssen J, Wesseling P, van den Heuvel LP, de Waal RM, Verbeek MM (2003) Heparin sulphate proteoglycans in Alzheimer's disease and amyloid-related disorders. Lancet Neurol 2:482-492.

Veerhuis R, Van Breemen MJ, Hoozemans JM, Morbin M, Ouladhadj J, Tagliavini F, Eikelenboom P (2003) Amyloid beta plaque-associated proteins $\mathrm{Clq}$ and SAP enhance the Abeta $1-42$ peptide-induced cytokine secretion by adult human microglia in vitro. Acta Neuropathol (Berl) 105:135-144.

Velazquez P, Cribbs DH, Poulos TL, Tenner AJ (1997) Aspartate residue 7 in amyloid beta-protein is critical for classical complement pathway activation: implications for Alzheimer's disease pathogenesis. Nat Med 3:77-79.

Walzer M, Lorens S, Hejna M, Fareed J, Hanin I, Cornelli U, Lee JM (2002) Low molecular weight glycosaminoglycan blockade of beta-amyloid induced neuropathology. Eur J Pharmacol 445:211-220.

Watson DJ, Lander AD, Selkoe DJ (1997) Heparin-binding properties of the amyloidogenic peptides Abeta and amylin. Dependence on aggregation state and inhibition by Congo red. J Biol Chem 272:31617-31624.

Webster S, Bonnell B, Rogers J (1997a) Charge-based binding of complement component $\mathrm{Clq}$ to the Alzheimer amyloid beta-peptide. Am J Pathol 150:1531-1536.

Webster S, Lue LF, Brachova L, Tenner AJ, McGeer PL, Terai K, Walker DG, Bradt B, Cooper NR, Rogers J (1997b) Molecular and cellular characterization of the membrane attack complex, C5b-9, in Alzheimer's disease. Neurobiol Aging 18:415-421.

Wyss-Coray T, Yan F, Lin AH, Lambris JD, Alexander JJ, Quigg RJ, Masliah E (2002) Prominent neurodegeneration and increased plaque formation in complement-inhibited Alzheimer's mice. Proc Natl Acad Sci USA 99:10837-10842.

Yasuhara O, Walker DG, McGeer PL (1994) Hageman factor and its binding sites are present in senile plaques of Alzheimer's disease. Brain Res 654:234-240.

Zhu H, Yu J, Kindy MS (2001) Inhibition of amyloidosis using lowmolecular-weight heparins. Mol Med 7:517-522.

Zlokovic BV, Ghiso J, Mackic JB, McComb JG, Weiss MH, Frangione B (1993) Blood-brain barrier transport of circulating Alzheimer's amyloid beta. Biochem Biophys Res Commun 197:1034-1040. 